\title{
市販鷄肉に打ける合成抗菌剂 NICARBAZINの
}

\section{残留について}

\author{
萬田芙美, 松下敏夫草上田 厚, 吉 岡 満 城 ${ }^{*}$ \\ 青山公治
}

近年, 畜産業や養殖業の生産過程において, 多種類かつ多量の抗菌性物質が使用されておう, 食 品への残留が懸念されている。著者らは, 合成抗菌剤 Nicarbazin (NCZ) の簡易分析法を検討し, 併せて市販鵎肉に括ける残留実態を検索し, NCZ の使用と安全性扣上び流通過程に括ける継続的な 監視の必要性に関して若干の考察を試みた。

残留 NCZ の分析は, 䳕肉の Acetonitrile 抽出物を直接 HPLCに注入する方法を用いた。本法は, 抽出物を脱脂, 脱水の前処理をすることによって, 煩雑な精製操作を省略し, 簡便かつ精度の高い 方法として，使用可能であった。

鹿児島市内の店舗より任意に購入した市販鶏肉について, NCZ の残留調査を実施したところ，そ の検出率は $13.0 \%(\mathrm{~N}=131)$ であった。季節的には, 夏季の疾病多発時, おょび月別では 12 月， 3 月之需要の多い時期に, 検出率が高い傾向が認められた。また, 鹿児島県外で購入した市販鷄肉か らも，ほぼ同様のレベル（検出率 $12.5 \% \mathrm{~N}=40$ ）で残留が認められた。

$\mathrm{NCZ}$ は鵎肉の中でも脂肪部位に多く蓄積し, 生物学的半減期が比較的長く, また特殊な毒性を有 することから，設定されている休薬期間の妥当性や，人体に対する安全性についてもより詳細な検 討が必要である。

(1)ナイカルバジン（nicarbazin） (2)市販鶏肉（commercial chicken） (3)残留（residue）

(4)抗菌性物質（antibacterials） (5)飼料添加物（feed additives）

\section{は じめに}

近年, 農業生産の近代化にともない, 農薬をはじめ 化学肥料, ホルモン剂抒よび抗生物質や合成抗菌剤な ぞの農業用化学物質が多量に使用されている。その人 体への影響については，直接それを使用する農業従事 者の健康障害と, 環境污染や食品への残留などからく る間接的な影響の 2 つの側面から考学なければならな い。農業用化学物質のらちで, 農薬は歷史的にも数多 くの被害をあた光，その健康への影響について広く研 究がなされているが，抗生物質や合成抗菌剤などの抗 菌性物質についての調査研究は、内外之もに極めて少 ない。しかしながら，抗生物質や合成抗菌剂は，今日， 畜産の多頭化や水産に打ける養殖業の発達にともなっ て, 疾病の予防や飼料効率の向上の目的で恒常的な使 用が不可欠のものとなっている。その結果, これらの

* 鹿児島大学医学部衛生学教室 （受付：昭和 60 年 4 月 13 日）
抗菌性物質の食品への残留が危惧され，さらには薬剤 耐性菌の増加による人の健康への影響も懸念されてい る。1975年 7 月に「飼料の安全性の確保および品質の 改善に関する法律」(飼料安全法)が改正され，安全な 食肉生産のために法的規制が強められるよらになった が，いまだに食品への残留の可能性は必ずしも否定で きないのが現状である。とくに，ブロイラーや養殖魚 は抗菌性物質の検査体制が整備されて招らず，屠殺時 に検査を受ける大家畜についても，その実施には問題 が多いと思われる。また，検查方法については，抗生 物質は生物学的試験によって比較的感度よく簡単に チェックできるが1), 合成抗菌剂は一般に操作が複雑 で，日常的な検查法としては，な敃検討の余地が残さ れている。

現在, 飼料添加物として使用が認められている合成 抗菌剤としては, Amprolium, Caprylhydroxamic acid, Clopidol, Decoqinate, Ethopabate, Nicarbazin, Olaquindox, Sulfaquinoxaline の 8 種類があるが，こ のうち Nicarbazin ( NCZ と略す) は, 鶏の抗コクシジ 
ウム作用を有することが知られ，産卵鶏用にはふ化後 10 週間まで，ブロイラー用には出荷前 7 日まで，それ ぞれ飼料 1 トンあたり 100 250 g および $100 〜 125 \mathrm{~g}$ の添加が法的に認められている。しかしながら，この ものは生物学的半減期が比較的長く, 食品中残留の可 能性が考兄られるにもかかわらず，その残留の実態や その際の毒性については明らかにされていない。そこ で, 著者らは，合成抗菌剤として NCZ に着目し，その 有用で簡易な分析法を検討し，併せて市販鶏肉におけ る残留の実態調査を行なった。

\section{材料および方法}

\section{1. 試料}

1983年 4 月より1984年 3 月までの 1 年間，毎月下旬 に鹿児島市内約 6 軒の店舗より市販鵎肉約 10 検体を任 意に購入し（合計131検体），実験に供した。また，あ わせて県外 (沖縄, 熊本, 福岡, 広島, 愛知, 長野, 東京）の市販鷄肉合計 40 検体を購入し，同様に実験に 供した（購入時期は1983年12月ょり1984年 3 月まで）。 2. 分析方法

鷂肉のNCZの分析は, Acetonitrile抽出物を直接, 高速液体クロマトグラフ（HPLC）に注入する星野ら の方法2を一部改変して行なった。即ち, 試料 $5 \mathrm{~g}$ 共检付遠心管にとり, Hyflo Super-Cel $1 \mathrm{~g}$ 抢よび Acetonitrile $20 \mathrm{ml}$ を加光，ホモジナイズしたのち $300 \mathrm{rpm} 5$ 分間遠心分離し上澄を分離する。残渣につい て Acetonitrile $10 \mathrm{ml}$ を加光, 同様に操作し上澄液を 合わせる。これに $\mathrm{n}$-Hexane $10 \mathrm{ml}$ を加えて振盪した 後, n-Hexane 層を除去し, Acetonitrile 層に無水硫酸 ナトリウム約 $7 \mathrm{~g}$ を加光て, 脱水後ろ過する。万液は ロータリー・エバポレーターで溶媒除去後, 残留物を 内部標準溶液 (1,5-dichloroanthraqinone $5 \mu \mathrm{g} / \mathrm{ml}$ Methanol） $1 \mathrm{ml}$ に溶解し,さらに遠心分離し, 上澄 液を試料溶液とする。この試料溶液 $25 \mu 1$ を直後 HPLC に注入する。この分析法の概略を図 1 亿示す。

3. NCZ の定性

1) 前記の方法に従って, 抽出, 溶媒除去して得ら れた残留物をChloroformに溶解した後, 畜水産物の 残留物質検査法 (公定法) ${ }^{3}$ 洼従って分離用アルミナカ ラムにてクリーンアップ後, 残留物を内部標準溶液 1 $\mathrm{ml}$ に溶解し HPLC に注入する。

2) 公定法の定性の項を応用した。即ち, 鵎肉の酢 酸エチル抽出物をアルミナカラムにてクリーンアップ 後, 残留物にアルカリ性 Acetone 溶液 $1 \mathrm{ml}$ を加光試 駼溶液とし，1 分以上放置後 $380 \sim 500 \mathrm{~nm}$ の吸収を測 定し, ついで, 試験溶液に酢酸 $0.05 \mathrm{ml}$ を加光, 混和し,

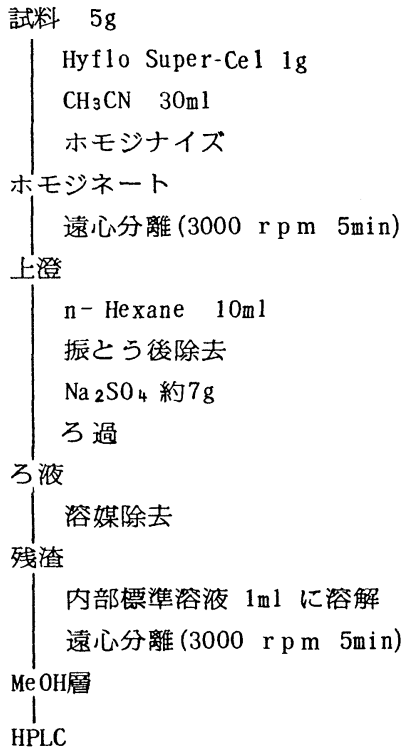

図 1。鵎肉中 Nicarbazin (NCZ) 分析法の概略

再び380 500 nm の吸収を測定する。酢酸添加前後の 吸光度の差をとって妨害物質の影響を除去し, NCZ の 標準溶液について同様にして得られたスペクトルと比 較し, 吸收極大波長が同じ波長であり吸収曲線が相似 であることを確かめる。

\section{結果}

I 。分析法の検討と NCZ の同定

1. 試料の前処理

試料を Acetonitrileで抽出したままでは，溶媒を除 去した際，試料によっては油状の残留物や水滴がかな り残るものがある。これを直接 HPLCに注入した場 合，初期に食品成分に由来する大きなピークをク口マ トグラフ上に出現させる。これは後続する NCZ の分 離に影響すると共に，カラムの劣化を速める原因とな る。そこで, n-Hexane による脱脂と無水硫酸ナトリウ ムによる脱水の操作を加えたところ, 回収率も低下さ せずクロマトグラム上の初期のピークも小さく，良好 な結果を得た。図 2 に, その代表的なクロマトグラム を示す。

\section{2. 添加回収実験}

あらかじめ NCZを含まないことを確かめた䳕肉 に， $0.4 \mu \mathrm{g} / \mathrm{g}$ の濃度の NCZを添加したものについて 回収実験を行なった結果, 平均回収率は $89.13 \pm 6.61 \%$ $(\mathrm{N}=5)$, 本法による検出限界は $0.02 \mu \mathrm{g} / \mathrm{g}$ であっ た。

3. NCZ の同定 


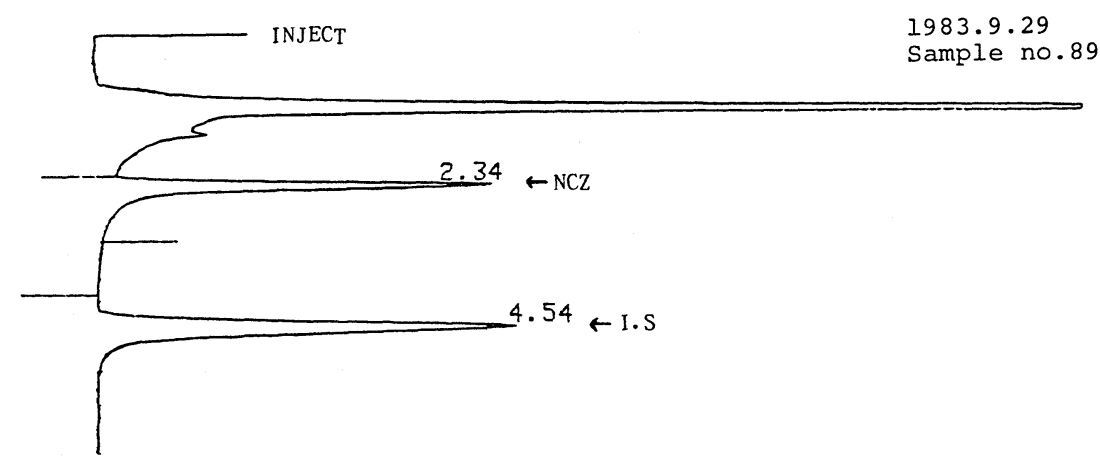

図 2. 市販䳕肉抽出物のクロマトグラム

HPLC 条件 カラム : Radial Pak C18

移動層： $\mathrm{CH}_{3} \mathrm{CN}-\mathrm{H}_{2} \mathrm{O}(7: 3)$

流量 $: 1 \mathrm{ml} / \mathrm{min}$

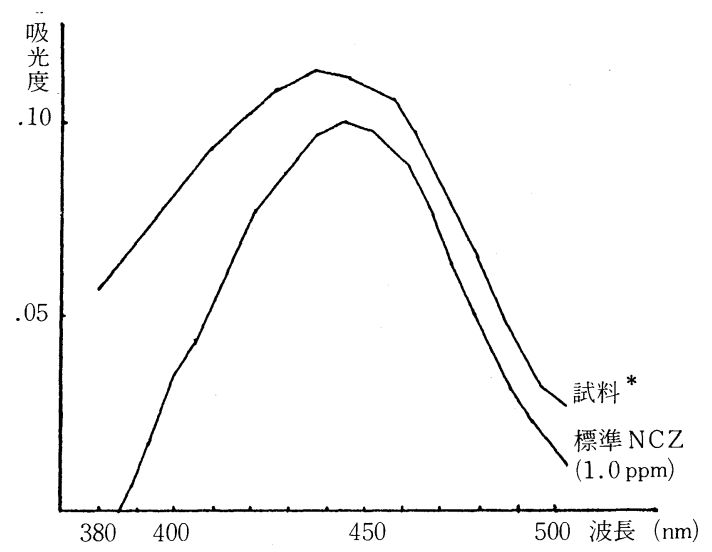

図 3.試料および標準 NCZ の吸収スペクトル

$* \mathrm{NCZ}$ 検出鶏肉 $20 \mathrm{~g}$ 上り調製（実験 3-2）

クリーンアップの操作を行なわずに粗抽出液を直接 HPLC に注入（直接法）した場合，他の夾雑物の影響 も想定され, Rt 值の比較のみから NCZ と断定するの は危険と考えた。そこで，直接法で NCZ と思われる ピークの出現した試料を用い, 公定法に従ってアルミ ナカラムを用いてクリーンアップ後 HPLCによって 分析した(実験方法 3-1)。その結果, クリーンアッ プ後も NCZ に該当する Rt 值のところにピークが認 められた。さらに実験方法 3-2に従って吸収スペク トルを描いた結果, $440 \mathrm{~nm}$ 付近に吸収極大がみられ $N C Z$ 標準液と相似した吸収曲線が得られた（図 3 ）。

以上の結果より，直接法で得られたピークは, NCZ によるものと判定した。

4. その他の妨害物質の検討

抗酸化剂として飼料に添加される Ethoxyquin も
検出器波長 : U.V. $340 \mathrm{~nm}$

試料注入量: $25 \mu \ell$

$340 \mathrm{~nm}$ に吸収があり, 鶏組織に残留して NCZ の分析 を妨害する可能性が考えられる。そこで, Ethoxyquin について HPLCを行なったところ，本条件下では NCZ の検出を妨害するものではなかった。

以上により, 鶏肉中の $\mathrm{NCZ}$ の分析において, 煩雑な 精製操作を省略して直接 HPLC に注入する方法は, 夾 雑物の妨害やカラムの劣化などのトラブルが予想され たが，脱脂，脱水の操作を加えることにより，簡便か つ迅速で精度の高い方法として日常的試験法に使用可 能であることが分かった。

II. 市販鶏肉中 $\mathrm{NCZ}$ 残留調査

上記の HPLC 直接法を用い, 市販鶏肉について残留 NCZ の測定を行なった。

表 1 に示すよらに，鹿児島市内で購入した試料につ いては，131検体中17検体(検出率 $13.0 \%$ )から NCZ が 検出され, その濃度は, $0.03 \sim 0.30 \mu \mathrm{g} / \mathrm{g}$ の範囲であっ た。そこで,これらの残留が鹿児島県内のみで認めら れるものか否かを検討するために，県外で購入した市 販鶏肉についても，分析を行なった。その結果，40検 体中 5 検体（検出率 $12.5 \%$ ）加検出され，濃度は $0.03 \sim 0.43 \mu \mathrm{g} / \mathrm{g}$ の範囲であった。鹿児島県内の検出 率について，母比率 $\mathrm{p}$ の区間推定を行なったところ, $7.2 \% \leqq \mathrm{p} \leqq 18.8 \%$ (信頼度 $95 \%$ ) であった。月別の平 均検出率打よび平均検出濃度を，それぞれ 3 項移動平 均法によって季節変動をみると, 図 4 に示すように, 検出率, 検出濃度ともに夏季に高い傾向が認められた。 しかしながら，12月，3月にも高い検出率が認められ， $4-6$ 月 (検出率 $6 \%$ )，7-9 月 $(20 \%), 10 \sim 12$ 月 ( $9 \%), 1-3$ 月 $(17 \%) の 4$ 期に分けた各期の検出 率には，有意な差異は認められなかった。

次に試料中 $\mathrm{NCZ}$ の体内分布をらかがうために，残 
表 1. 市販鵎肉中 NCZ 残留状況

\begin{tabular}{|c|c|c|c|c|}
\hline 収集年月 & 検体数 & 検出数 & $\begin{array}{c}\text { 検出率） } \\
\%\end{array}$ & $\begin{array}{c}\text { 検出濃度 }(\mathrm{ppm}) \\
\min . \sim \text { average } \sim \max .\end{array}$ \\
\hline \multicolumn{5}{|l|}{ 鹿児島市 } \\
\hline 1983年 4 月 & 10 & 1 & (10) & 0.19 \\
\hline 5 & 12 & 1 & ( 8$)$ & 0.07 \\
\hline 6 & 11 & 0 & $(0)$ & 一 \\
\hline 7 & 10 & 2 & $(20)$ & 0.03 \\
\hline 8 & 15 & 3 & $(20)$ & $0.04 \sim 0.07 \sim 0.11$ \\
\hline 9 & 10 & 2 & $(20)$ & $0.06 \sim 0.18 \sim 0.30$ \\
\hline 10 & 10 & 0 & $(0)$ & - \\
\hline 11 & 9 & 0 & $(0)$ & - \\
\hline 12 & 14 & 3 & $(21)$ & $0.03 \sim 0.03 \sim 0.04$ \\
\hline 1984年 1 月 & 7 & 0 & $(0)$ & - \\
\hline 2 & 13 & 1 & ( 8$)$ & 0.05 \\
\hline 3 & 10 & 4 & $(40)$ & $0.03 \sim 0.06 \sim 0.10$ \\
\hline 計 & 131 & 17 & (13) & $0.03 \sim 0.07 \sim 0.30$ \\
\hline 県外* ${ }^{\text {計 }}$ & 40 & 5 & (13) & $0.03 \sim 0.19 \sim 0.43$ \\
\hline
\end{tabular}

* 収集年月 1983 年12月 1984 年3月

留 $\mathrm{NCZ}$ が検出された検体 1 例(検出濃度 $0.19 \mathrm{ppm}$ ) に ついて, 脂肪部位のみと筋肉部位のみを別々に採取し， それぞれの残留 NCZを測定した。その結果, 同一検体 でも, 筋肉部位のみを採取した場合は、検出濃度が 0.04 $\mathrm{ppm}$, 脂肪部位のみで $0.22 \mathrm{ppm}$ と異なる值が得られ, $\mathrm{NCZ}$ が脂肪部位に多く残留していることが分かった。

\section{考察}

結果で述べたごとく, 鷄肉中 $\mathrm{NCZ}$ の測定に, 煩雑な 精製操作を省略して鵎肉の Acetonitrile 抽出物を直 接 HPLC に注入する方法は, 簡便かつ精度の高い方法 として有用である。

NCZ の残留調査例は, Clopidol に比べて非常に少 なく,その実態は十分把握されているとは言い難いが, 能勢ら ${ }^{4) 5}$ は，1978年から1980に埼玉県下の鶏肉につい て調查し，1980年のみ 30 検体中 1 例（検出率 $2.6 \%$ ) か ら検出, 星野ら ${ }^{2)}$ は, 50 検体中 4 例（検出率 $8 \%$ ）に $\mathrm{NCZ}$ の検出を認めている(分析時期不明)。今回の我々 の調査では，これらを上廻る検出率が観察されたが， これには二つの要因が考兄られる。一つは試料の測定 部位に関するもので，脂肪を含まない筋肉部位のみを 採取した場合は，検出率が低くなると予想される。他 は使用薬剂の種類の変化で，これまで抗コクジゥム剤 として広く使用され, かつ, その残留が問題とされて
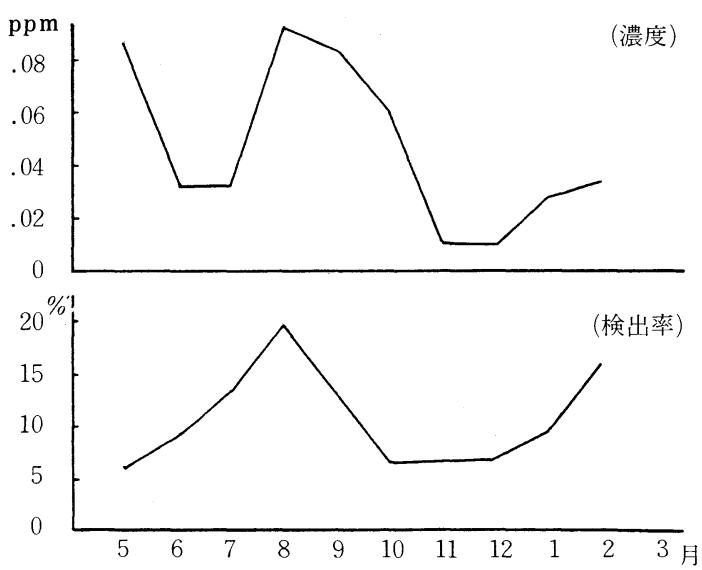

図 4.三項移動平均法による鶏肉中 $\mathrm{NCZ}$ 検出状況の季節変動

きたClopidol の検出例が年々減少していること, 拈よ び鹿児島県内の飼料添加物の使用状況調査の結果等か らあわせて考㝋ると，抗コクジゥム剤としてClopidol にかわって NCZ の使用が増加していることも推定さ れる。いずれにせよ，鹿児島県外の試料からも皃涪同 じレベルで残留が観察されたことから，全国的に広範 な残留が予想され，今後厳しい監視が望まれる。

な抢, 検出率, 検出濃度とも夏季に高い傾向を認め たことは, 高温多湿期における飼育鷄の疾病の多発と 関連するものであろう。また，12月， 3 月など需要の 増大する時期にも検出率の上昇が認められており, こ のような季節的変動についても, 今後留意して行く必 要があろう。

このような NCZの鶏肉中への残留の原因として は, ブロイラーの飼育段階で, 休薬期間を置かずに出 荷されていることや，配合飼料製造工程で，本来抗菌 剂が入ってはならない休薬期間用の飼料への NCZの 混入が疑われる。これまで， $0.0125 \%$ の NCZを含む 飼料を鶏に連続投与した場合, 投薬中止後 4 日後に は筋, 肝, 腎, 皮膚, 脂肪などからナイカルバジンは 検出されないとされていたが6), 能勢らブ 器や脂肪組織からの消失には約 10 日要したと, その消 失の遅さを指摘している。したがって, NCZ の生物学 的半減期の長さや脂肪組織への蓄積性を考光ると, 設 定された休薬期間がはたして適当なものであるかどう かについてもさらに検討する必要があるものと思われ る。

NCZ の一般毒性については洼とんど報告がないが， 神蔵(6)の解説によれば, 本品の急性毒性は $\mathrm{LD}_{50} 20 \mathrm{~g} /$ $\mathrm{kg}$ 以上(マウス, ラット, 経口), 亜急性毒性試験の結 
果から得られた最大無作用量は，ラットについて1600 $\mathrm{mg} / \mathrm{kg}$ 以上であるとされている。我々の調査から検出 された鶏肉中の残留值の最高濃度のもの $(0.43 \mu \mathrm{g} / \mathrm{g})$ を仮に一日 $1 \mathrm{~kg}$ 食べたとしても，NCZの摄取量は $0.43 \mathrm{mg}$ となり, 最大無作用量と比較したかぎりでは 健康上即有害とは言光ないであろう。しかしながら， 鵎では NCZ の投与により産卵が阻害されることはよ く知られた事実であり, Luck ら ${ }^{8)}$ は，このことは，多 分 NCZ が視床下部のホルモン刺激機能に悪影響を招 よぼすためであろうとしている。能勢らりは，鶏に $0.0125 \%$ NCZ を含む飼料を給与後 7 日目で産卵の 停止を観察し, NCZ 添加中止後10日目で産卵を開始し たが，卵から NCZ の残留值が0.01 ppm 以下になる亦 でには1ケ月近く必要としたと報告している。また産 卵を停止させるには至らない程度の低レベルの投与で も，卵の質に悪影響を及ぼすことが観察されてい る $^{910)}$ 。Cuckler $ら^{11)}$ は, NCZ 牛に投与 $(200 \mathrm{mg} / \mathrm{kg})$ した場合, 臨床的には正常と思われたが，解剖の結果， 腎臓の肥大と損傷を観察して抢り，代謝産物の影響を 示唆している。

さらにOhta ら ${ }^{12)}$ は, 18 種類の飼料添加物の変異原 性試験を行ない，そのなかで NCZについてはRec -assay では陰性であったものの, サルモネラ菌を用い た Reverse mutation assayではTA1538と TA98株 で弱いながら陽性であったと報告している。以上述べ た NCZ の有する特異的な毒性から考えると, NCZの 使用にあたっては, 哺乳類を対象にした繁殖能に対す る影響やその他の毒性について, より詳細な検討が必 要なものと思われる。

以上, ブロイラー生産で多用されている合成抗菌剂 の食品への残留といら観点から NCZ 対象にしてそ の実態を調査し若干の考察を加えたが, 一般に動物医 薬品捛よび飼料添加物の汪とんどのものは, 安全性を 評価するに足る十分なデータが蓄積されておらず，未 だADI ( 1 日摂取許容量)の設定される段階には至って いない。従って, 現時点では, 食品中に残留しないこ とが唯一の食品衛生上の安全確保の手段として必要で あり, 生産者の努力と, 継続的な監視が望まれる。

$$
\text { ま と め }
$$

鷄の抗コクジゥム剂として飼料に添加されている $\mathrm{NCZ}$ の簡易分析法を検討し, 併せて市販鵎肉中の残留 実態を調査した。

1.鷄肉の Acetonitrile 抽出物を直接 HPLC に注入す る NCZ の簡易分析法は, 脱脂, 脱水の操作を加えるこ とによって, 迅速かつ精度の高い方法として日常的に
使用可能である。本法による平均回収率は $89.13 \pm$ $6.61 \%(0.4 \mu \mathrm{g} / \mathrm{g}$ 添加), 検出限界は $0.02 \mu \mathrm{g} / \mathrm{g}$ であっ た。

2. 鹿児島県内扰よび県外 7 地域(沖縄, 熊本, 福岡, 広島, 愛知, 長野, 東京)で購入した検体について NCZ の残留調查を実施したところ, それぞれ131検体中 17 検 体(検出率 $13.0 \%$, 検出濃度 $0.03 \sim 0.30 \mu \mathrm{g} / \mathrm{g}$ ), 40 検体 中 5 検体 (検出率 $12.5 \%$, 検出濃度 $0.03 \sim 0.43 \mu \mathrm{g} / \mathrm{g}$ ) から NCZ が検出された。また, 鹿児島市に打ける検出 率の季節変動を見たところ, 夏季に検出率が高い傾向 が認められた。月別には，12月， 3 月といった需要の 増大する時期にも上昇をみたが，統計的に有意な差異 は認められなかった。

$\mathrm{NCZ}$ は鷄肉の中でも脂肪部位に多く蓄積し, 生物学 的半減期が比較的長く，また特殊な毒性を有すること から，設定された休薬期間の妥当性や，人体に対する 安全性についてもょり詳細な検討が必要である。

\section{謝辞}

本研究を行ならにあたり，HPLC 分析と御援助，御助言を頂き ました鹿児島大学医学部附属病院薬剂部本屋敏郎先生ならびに, $\mathrm{NCZ}$ 標品を御提供頂きむした大日本製薬株式会社に感謝の意を 表します。

\section{文献}

1）厚生省環境衛生乳肉衛生課：畜水産食品中の残留物質検查 法，第 1 集，II．枝肉の抗菌性物筫簡易検査法，1977。

2）星野庸二・他：高速液体クロマトグラフィーによる鵎肉拉上 び鶏卵中ナイカルバジンの定量, 食衛誌, 23(3), 259-269, 1982.

3）厚生省環境衛生局乳肉衛生課：畜水産食品中の残留物質検 查法 第 2 集の 2,1978 .

4 ）能勢憲英：畜産食品中の合成抗菌剤の残留調查, 埼玉県衛生 研究所報, 15, 120-124, 1981.

5 ）能勢憲英・他：ガスクロマトグラフィーによるNicarbazin の定量, 食衛誌, $22(6) ， 496-500,1981$.

6）神蔵美枝子：畜産食品中に批斿合成抗菌剤の検查法につ いて（そのII），食品衛生研究，28(11)，1051-1062， 1978.

7 ）能勢憲英・他：飼料添加物合成抗菌剂の二ワトリ組織及び鷄 卵中の残留と消失, 食衛誌，23(3)，246-252，1982。

8 ) Luck, M. R.: The adverse effect of nicarbazin on reproductive activity in the hen, Br. Poult. Sci. $20: 605-607$, 1979.

9) Backer, R. C. et al.: The effect of nicarbazin on egg production and egg quality, Poult. Sci., $36: 718-726,1957$.

10) Silvestrini, D. A. et al. : Effect of nicarbazin in diet on mottled yolks, Poult. Sci., 44 : 467-473, 1964.

11) Cuckler, A. C. et al. : A metabolite of nicarbazin, Proc. Soc. Exp. Biol. Med., 93 : 248-251, 1956.

12) Ohta, T. et al. : Mutagenity screening of feed additives in the microbial system, Mutat. Res., 77 : 21-30, 1980. 


\title{
Studies on the Residues of Nicarbazin in Commercial Chickens
}

\author{
Fumi MANDA*, Toshio MATSUSHITA*, Atsushi UEDA*, \\ Mitsuki YOSHIOKA* and Kohji AOYAMA*
}

A simple and sensitive method for the determination of residual Nicarbazin (NCZ) by high performance liquid chromatography (HPLC) was examined to apply to livestock products. And the detection of residual $\mathrm{NCZ}$ in commercial chickens was also investigated.

1. The method that the acetonitrile extracts of meat homogenate were injected directly into HPLC was able to apply to determine the residual NCZ by adding process of degreasing and dehydration of the extracts. The average recovery of $\mathrm{NCZ}$ added to the chicken muscle $(0.4 \mu \mathrm{g} / \mathrm{g})$ were $89.13 \pm 6.61 \%(\mathrm{~N}=5)$ and detection limit in this analytical procedure was $0.02 \mu \mathrm{g} / \mathrm{g}$.

2. Using the above method for the analysis of NCZ in commercial samples, the frequency of detection was $13.0 \%$ and the range of concentration was $0.03 \sim 0.30 \mu \mathrm{g} / \mathrm{g}$ in samples collected from Kagoshima city $(\mathrm{N}=131)$. The residual $\mathrm{NCZ}$ in commercial chickens showed a tendency to increase in summer season. The similar levels of frequency $(12.5 \%)$ and concentrations $(0.03 \sim 0.43 \mu \mathrm{g} / \mathrm{g})$ were found in samples collected from other prefectures $(\mathrm{N}=40)$.

\footnotetext{
* Depertment of Hygiene, Faculty of Medicine, Kagoshima University.
} 